\title{
PENERJEMAHAN AKSARA HAN PADA BONGPAY DI MUNTANG-TANJUNG BANYUMAS MENGGUNAKAN METODE KOMUNIKATIF
}

\author{
Nurhayati \\ Program Studi D3 bahasa Mandarin Fakultas Ilmu Budaya Universitas Jenderal Soedirman, Purwokerto \\ E-mail: nuoni.zf@gmail.com.
}

\begin{abstract}
ABSTRAK
Artikel ini membahas tentang penerjemahan aksara Han pada batu nisan (Bongpay) di Muntang-Tanjung Banyumas menggunakan metode komunikatif. Tujuan penelitian ini adalah mengidentifikasi tulisan aksara Han yang terdapat pada batu nisan (Bongpay) di MuntangTanjung Banyumas. Penelitian ini menggunakan metode deskriptif kualitatif. Objek penelitian ini adalah batu nisan (Bongpay) di Muntang-Tanjung Banyumas. Hasil analisis menunjukkan bahwa penerjemahan menggunakan metode komunikatif dapat memahami makna yang tertulis pada batu nisan (Bongpay) dari bahasa Tionghoa ke dalam bahasa Indonesia.
\end{abstract}

Kata kunci : aksara Han, batu nisan, metode komunikatif

\begin{abstract}
This article discusses about translation of Chinese Character on tombstone in MuntangTanjung Banyumas uses communicative method. The objective of this article is to identify Chinese character that written on tombstone in Muntang-Tanjung Banyumas. The research uses the descriptive qualitative method. The tombstone in Muntang-Tanjung Banyumas as object of this research. The results show that uses communicative method in translating tombstone from Mandarin to Indonesian, can understand the meaning that written on that tombstone.
\end{abstract}

Keywords : Chinese character, tombstone, communicative method

\section{A. PENDAhuluan}

Orang-orang Tiongkok datang ke Indonesia diperkirakan sejak abad ke-11, mereka merantau ke beberapa negara di Asia Tenggara, salah satunya Indonesia. Orang-orang perantau dari Tiongkok tersebut membentuk perkampungan di beberapa daerah di pulau Jawa. Mereka membawa tradisi, norma-norma dan sikap fanatisme terhadap tradisi leluhur. Ajaranajaran yang berisi pandangan hidup seperti Budhisme, Taoisme, dan Kong $\mathrm{Hu} \mathrm{Cu}$ merupakan pemikiran mereka, Husodo (1985). Tradisi-tradisi tersebut masih dilestarikan oleh masyarakat Tionghoa hingga saat ini. Namun, melewati sejarah panjang masyarakat Tionghoa di Indonesia menyebabkan terjadinya akulturasi budaya baik yang dipengaruhi oleh budaya Indonesia, maupun budaya Eropa. Pada jaman penjajahan Belanda, hubungan masyarakat 
Tionghoa dan pemerintah Hindia-Belanda sangat erat. Terwujud pada seni dan budaya masyarakat Tionghoa. Bukti akulturasi budaya Tionghoa yang dipengaruhi oleh budaya Eropa adalah perubahan seni arsitektur makam yang ada di Muntang-Tanjung Banyumas. Sedangkan, bukti akulturasi budaya Tionghoa yang dipengaruhi oleh budaya Indonesia adalah pembuatan meja altar pada makam, batu nisan dan lekukan pada bagian atas batu nisan dihitung berdasarkan tanggal lahir mendiang menurut penanggalan Jawa. Tulisan pada batu nisan tersebut, tidak semua menggunakan aksara Han, melainkan menggunakan bahasa Indonesia, baik ejaan yang belum disempurnakan maupun ejaan yang sudah disempurnakan. Walaupun terdapat perbedaan tata cara penulisan antara bahasa Indonesia dan bahasa Tionghoa, namun sama dalam penulisan nama mendiang ayah di sebelah kanan, dan penulisan nama mendiang ibu di sebelah kiri. Perbedaannya terletak pada penulisan tanggal lahir, tanggal wafat, dan nama anak-anak serta cucu-cucu.

Tulisan aksara Han pada batu nisan menggunakan tulisan tradisional Tiongkok yang disebut dengan 繁体字 (fantizi), tulisan ini pertama kali muncul pada masa Dinasti Han (201 SM - 220 M) dan digunakan sejak abad ke-5. Saat ini tulisan tradisional Tiongkok digunakan di Taiwan, Hongkong, dan Makau. Sedangkan Tiongkok menggunakan aksara Han yang telah disederhanakan, yang disebut dengan 简体字 (jiantizi). Aksara ini diperkenalkan pada tahun 1950-an. Perbedaan dari kedua aksara ini terletak pada tingkat kerumitan penulisannya. Menurut Nio Joe Lan (1961) tulisan tradisional Tiongkok lebih dari dua puluh guratan, namun setelah disederhanakan tidak hanya mengurangi jumlah guratannya, melainkan juga menciptakan aksara lain yang lebih mudah penulisannya.

Tujuan dari penelitian ini adalah ingin mengetahui makna aksara Han yang tertulis pada batu nisan (Bongpay) dengan menggunakan metode komunikatif, dan metode penerjemahan yang penulis gunakan adalah metode yang dikemukakan oleh Newmark.

\section{B. MATERI DAN METODE}

\subsection{Tulisan Aksara Han pada Batu Nisan (Bongpay)}

Kata Bongpay berasal dari bahasa Hokkian yang artinya batu nisan. Dalam bahasa Tionghoa disebut 墓碑 (mùbēi). Bongpay pada makam tradisional Tionghoa memiliki perbedaan dalam bentuk dan cara penulisannya. Tata cara penulisan dan cara membaca aksara Han pada Bongpay yaitu dari kanan ke kiri dan dari atas ke bawah, dan tulisan aksara Han pada Bongpay terdiri atas empat bagian, yaitu:

a. Baris kanan. Tulisan yang terdapat pada baris kanan adalah tanggal peletakan atau perbaikan Bongpay. Umumnya ditulis berdasarkan penanggalan Tiongkok. Cara 
penulisannya mengikuti aturan $(5 n+1)=6,11,16$ karakter dan kelipatannya, yang memiliki makna 'lahir' berdasarkan lima karakter perhitungannya yaitu lahir, tua, sakit, derita, dan mati.

b. Baris tengah. Tulisan yang terdapat pada baris tengah adalah nama dan status mendiang selama hidup. Pada bagian atas nama terdapat kata 显考 (xiăn kăo) artinya mendiang ayah dan 显妣 (xiăn b̆) artinya mendiang ibu. Pada bagian bawah nama mendiang terdapat kata 墓 (mù) yang artinya makam atau 之墓 (zhī mù) yang artinya pemilik makam. Cara penulisan nama juga mengikuti aturan $(5 n+2)=7,12,17,22$ karakter dan kelipatannya, yang memiliki makna 'tua' berdasarkan lima karakter perhitungannya yaitu lahir, tua, sakit, derita, dan mati.

c. Baris horizontal (mata Bongpay). Mata Bongpay yaitu tulisan yang terdapat pada bagian kanan dan kiri atas Bongpay, yang merupakan nama daerah (kabupaten) keluarga mendiang berasal, nama kampung halaman mendiang, peristiwa besar mengenai keluarga mendiang, atau jumlah generasi mendiang dalam silsilah keluarga.

d. Baris kiri. Tulisan yang terdapat pada baris kiri adalah nama anak-anak dan cucu-cucu mendiang dari anak laki-laki. Jika tidak memiliki anak laki-laki, menuliskan nama anak perempuan dengan jumlah karakter mengikuti aturan $(5 n+1)=6$ karakter.

\subsection{Metode Komunikatif}

Beberapa ahli telah mengemukakan berbagai macam metode penerjemahan, salah satunya adalah klasifikasi yang dikemukakan oleh Newmark. Newmark membagi metode penerjemahan ke dalam dua kelompok, yaitu metode yang berpihal pada bahasa sumber dan metode yang berpihak pada bahasa sasaran. Newmark (1988) menggambarkan metode penerjemahan tersebut seperti diagram $\mathrm{V}$ berikut ini :

\section{SL emphasis}

Word-for-word translation

Literal translation

\section{Faithful translation}

Semantic translation

TL emphasis

Adaptation

\section{Free translation}

\section{Idiomatic translation}

\section{Communicative translation}

Dari delapan metode penerjemahan yang diklasifikasikan oleh Newmark ini, penulis akan memaparkan salah satu metode penerjemahan yaitu tmetode penerjemahan komunikatif. Metode penerjemahan komunikatif termasuk dalam metode yang berpihak pada bahasa sasaran. Metode ini berusaha menyampaikan sedemikian rupa makna kontekstual dari bahasa sumber, sehingga isi dan bahasanya berterima dan pembaca bahasa sasaran dapat 
memahaminya. Menurut Newmark (1988) metode penerjemahan komunikatif lebih sederhana, lebih singkat, lebih jelas dan lebih alami dalam penyampaian pesan. Metode penerjemahan komunikatif dilakukan dengan mempertimbangkan tingkat kematangan berbahasa dan tingkat pengetahuan pembaca teks bahasa sasaran.

Seorang penerjemah dalam menerjemahkan sebuah teks dengan menggunakan metode komunikatif bekerja dalam konteks variasi bahasa dan budaya sasaran dalam mengadaptasi pikiran, pesan, budaya, gaya bahasa, struktur semantik dan sintaksis dalam teks bahasa sumber, sehingga penerjemah boleh untuk mengoreksi, mengubah logika penulisan, gaya penulisan, dan juga membetulkan informasi teks bahasa sumber, Newmark (1981).

Menurut Sayogie (2014) dalam penerjemahan sebuah teks menggunakan metode penerjemahan komunikatif dapat dilakukan melalui beberapa tahap, yaitu:

1. Tahap membaca. Penerjemah terlebih dahulu membaca teks yang akan diterjemahkan untuk mendapatkan pesan teks bahasa sumber.

2. Tahap analisis. Penerjemah mulai menganalisis kalimat-kalimat yang terdapat pada teks bahasa sumber. Mengoreksi jika terdapat kesalahan kemudian melakukan pengaturan informasi agar pesan dalam bahasa sasaran dapat disampaikan secara utuh.

3. Tahap pengalihan. Penerjemah melakukan pengalihan pesan dengan tetap mempertahankan informasi teks bahasa sumber yang sudah disederhanakan bahasanya.

4. Tahap penyerasian. Penerjemah melakukan perbandingan teks bahasa sumber dengan teks yang telah diterjemahkan untuk melihat penggunaan bahasa yang sesuai dan gaya bahasa yang wajar.

\subsection{Metode penelitian}

Metode penelitian ini merupakan metode yang bersifat deskriptif yang merupakan bagian dari penelitian kualitatif. Penelitian deskriptif kualitatif merupakan uraian data bukan dalam bentuk angka-angka, melainkan dalam bentuk gambar-gambar atau kata-kata. Dalam penelitian ini penulis akan memaparkan makna tulisan aksara Han yang terdapat pada batu nisan (Bongpay) di Muntang-Tanjung Banyumas menggunakan metode penerjemahan komunikatif. Dan penjelasan dalam bahasa Tionghoa menggunakan aksara Han yang telah disederhanakan 简体字 (jiantizi). Objek penelitian ini adalah batu nisan (Bongpay) di Muntang-Tanjung Banyumas.

\section{HASIL DAN PEMBAHASAN}


Pada bab ini penulis akan memaparkan makna tulisan aksara Han yang terdapat pada batu nisan (Bongpay) di Muntang-Tanjung Banyumas dengan menggunakan metode komunikatif.

Contoh 1:

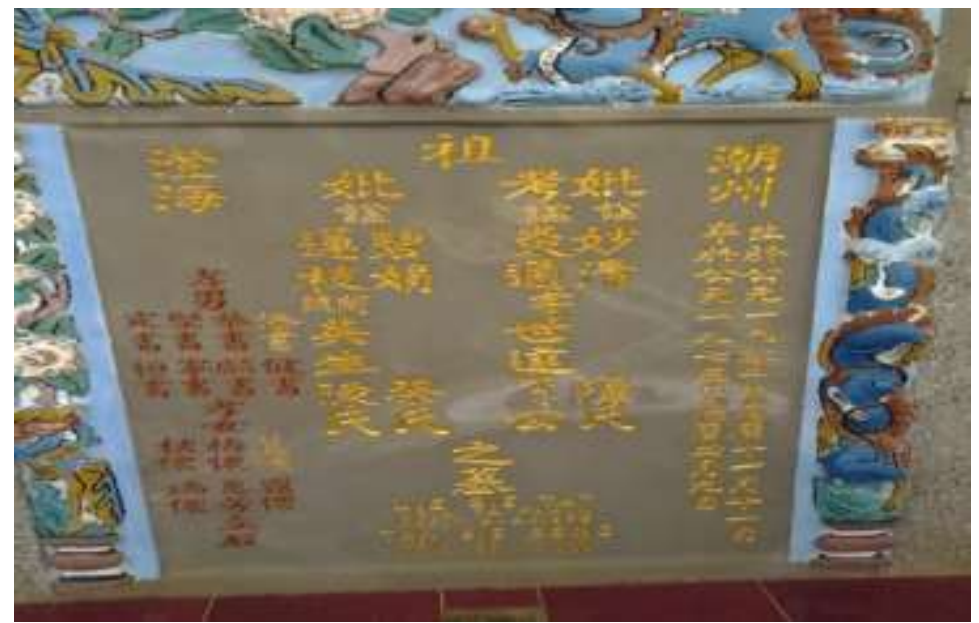

Tulisan aksara Han yang terdapat pada baris kanan Bongpay adalah tanggal lahir dan tanggal wafat mendiang ayah menggunakan penanggalan Tiongkok dan penanggalan masehi. Tanggal lahir mendiang ayah yaitu tanggal 11 bulan 11 tahun 1902 berdasarkan penanggalan Tiongkok (一九零二年农历十一月十一日 ya jiŭ líng èr nián nónglì shíȳ̄ yuè shíyı̄ rì), dsn tanggal wafat mendiang ayah yaitu 9 April 1975 berdasarkan penanggalan masehi (一九七五

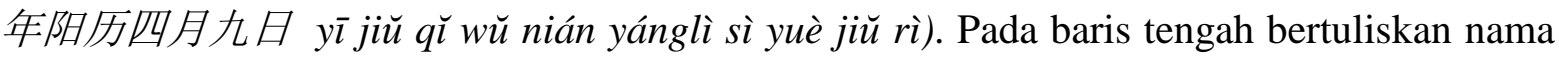
mendiang ayah, nama mendiang istri pertama, nama mendiang istri kedua, dan nama mendiang istri ketiga. Nama mendiang istri pertama ditulis di sebelah kanan nama mendiang suami/ ayah, dan di sebelah kirinya bertuliskan nama mendiang istri kedua dan mendiang istri ketiga. Di atas nama mendiang ayah terdapat kata考谥 (kăoshì) yang artinya nama mendiang ayah. Nama mendiang ayah adalah 炎通 (Yántōng), dan di bawahnya bertuliskan nama marga

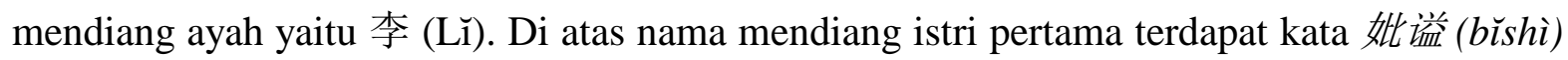
yang artinya nama mendiang ibu. Nama mendiang istri pertama adalah 妙清 (Miàoqīng), dan di bawahnya bertuliskan nama marga mendiang istri pertama yaitu 陈 (Chén). Di atas nama mendiang istri kedua dan mendiang istri ketiga terdapat kata 妣谥 (bishì) yang artinya nama mendiang ibu. Nama mendiang istri kedua adalah 碧娟 (Bìjuān), dan di bawahnya bertuliskan nama marga mendiang istri kedua yaitu 蔡 (Cài). Nama mendiang istri ketiga adalah 连枝 (Liánzhī), dan di bawahnya bertuliskan nama marga mendiang istri ketiga yaitu 冻 (Dòng). Di 
bagian bawah nama mendiang terdapat kata 之墓 $(z h \bar{\imath} m u ̀)$ yang artinya pemilik makam. Pada bagian bawah ini, bertuliskan nama mendiang ayah dan nama mendiang istri pertama, usia dan tanggal wafat yang ditulis dalam bahasa Indonesia.

Selanjutnya, pada baris horizontal (mata Bongpay) bertuliskan nama kota dan nama kecamatan keluarga mendiang berasal. Nama kota asal keluarga mendiang adalah 潮州 (Cháo zhōu), ditulis di sebelah kanan atas dengan bentuk vertikal. Dan nama kecamatannya adalah 澄海 (Chéng hăi), ditulis di sebelah kiri atas dengan bentuk vertikal. Pada baris kiri bertuliskan nama-nama putra dan nama-nama putri mendiang. Di atas nama-nama putra terdapat kata 男 (xiào nán) yang artinya anak laki-laki yang berbakti, dan di atas nama-nama putri mendiang

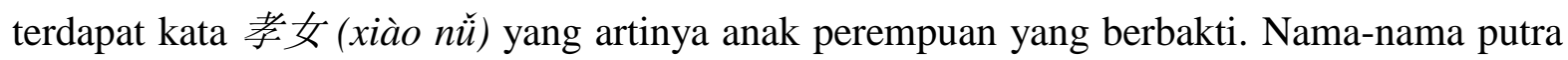
dan putri mendiang yang berwarna merah, menandakan bahwa putra-putri mendiang tersebut masih hidup, sebaliknya nama putra dan putri mendiang yang berwarna kuning atau emas, menandakan bahwa putra dan putri mendiang tersebut sudah meninggal

Contoh 2 :

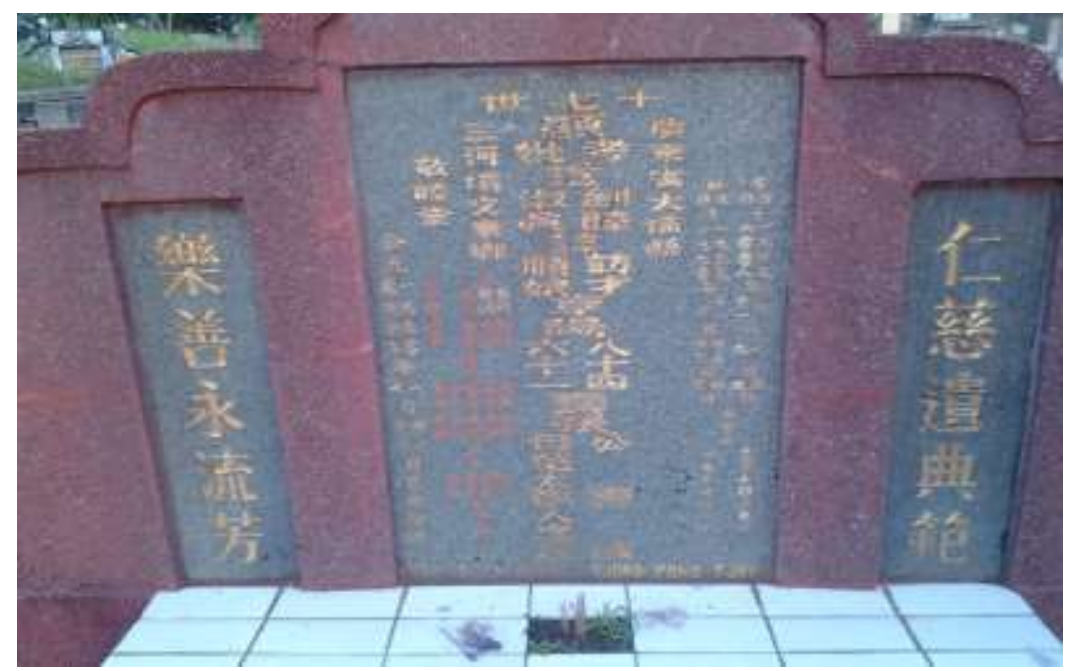

Tulisan aksara Han yang terdapat pada baris kanan Bongpay adalah tanggal lahir dan tanggal wafat mendiang ayah dan mendiang ibu menggunakan penanggalan masehi. Tanggal lahir mendiang ayah yaitu 8 Juli 1925 (一九二五年七月八 日 ȳ̄ jiǔ èr wŭ nián qū yuè bā rì), dan tanggal wafat mendiang ayah yaitu 9 November 2008 (二零零八年十一月九日 èr líng líng bā nián shí ȳ yuè jiŭ rì). Tanggal lahir mendiang ibu yaitu 23 November 1933 (一九三 三年十一月二十三日 ȳ̄ jiŭ sān sān nián shí yē yuè èr shí sān rì), dan tanggal wafat mendiang ibu yaitu 13 Juni 1990 (一九九零年六月十三日 yī jiŭ jiŭ líng nián liù yuè shí sān 
rì). Di bawah tanggal lahir dan tanggal wafat mendiang bertuliskan tanggal mendiang ayah dan mendiang ibu dimakamkan. Mendiang ayah dimakamkan pada 14 November (十一月十 四日 shí ȳ̃ yuè shí sì ri), dan mendiang ibu dimakamkan pada 17 Juni (六月十七日 liù yuù shí qī rì).

Pada baris tengah bertuliskan nama mendiang ayah, nama mendiang ibu, nama provinsi, kabupaten dan nama desa keluarga mendiang berasal. Nama mendiang ibu ditulis di sebelah kiri nama mendiang ayah. Di atas nama mendiang ayah terdapat kata考谥 (kăoshì) yang artinya nama mendiang ayah. Nama mendiang ayah adalah 创睦 (Chuàngmù), dan di bawahnya bertuliskan nama lain mendiang ayah yaitu 访才 (Făngcái), dan nama marganya adalah 张 (Zhāng). Di atas nama mendiang ibu terdapat kata 妣谥 (b̆̌shì) yang artinya nama mendiang ibu. Nama mendiang ibu adalah 淑真 (Shūzhēn), dan di bawahnya bertuliskan nama lain mendiang ibu yaitu 顺娘 (Shùnniáng), dan nama marganya adalah 范 (Fàn). Di kanan dan di kiri nama mendiang bertuliskan nama provinsi, kabupaten dan nama desa keluarga mendiang berasal. Di sebelah kanan nama mendiang ayah bertuliskan kalimat 广东省大埔县 (Guăngdōng shěng Dàbù xiàn) yang artinya kabupaten Dabu, provinsi Guangdong. Dan di sebelah kiri nama mendiang ibu bertuliskan desa asal keluarga mendiang, yaitu desa Wendong (文东 Wéndōng) bendungan 三河 (sān hé).

Selanjutnya, pada baris kiri bertuliskan nama-nama putra mendiang, nama cucu laki-laki, dan cucu perempuan mendiang, juga tanggal peletakan batu nisan. Di atas nama putra mendiang terdapat kata 男 (nán) yang artinya anak laki-laki, di atas nama cucu laki-laki mendiang terdapat kata 孙男 (sūn nán) yang artinya cucu laki-laki, dan di atas nama cucu perempuan terdapat kata 孙女( $(\bar{u} n n \check{\ddot{u}})$ yang artinya cucu perempuan. Nama-nama putra dan cucu mendiang yang berwarna merah, menandakan bahwa putra dan cucu mendiang tersebut masih hidup, sebaliknya nama putra mendiang yang berwarna kuning atau emas, menandakan bahwa putra mendiang tersebut sudah meninggal. Di sebelah kiri nama anak-anak dan cucu mendiang bertuliskan tanggal peletakan batu nisan yaitu pada 31 Agustus 1990 (一九九零年 八月三十一日yī jiŭ jiŭ líng nián bá yuè sān shí yĩ rì) dan penyebutan tahun pada penanggalan Tiongkok yaitu tanggal 12 bulan 7 tahun 1990 (一九九零年七月十二日 yī jiŭ jiŭ líng nián qī yuè shí èr rì).

Pada sisi kanan dan sisi kiri Bongpay bertuliskan petuah dalam bahasa Tionghoa. Petuah tersebut yaitu 仁慈遗典范 (èr cì yí diăn fàn) diterjemahkan menjadi kebajikan dan 
kesabaran hati akan mewariskan contoh yang baik; 乐善永流芳 (lè shàn yŏng liú fàng) diterjemahkan menjadi suka berbuat kebaikan akan membuat namanya harum selamanya.

\section{Contoh 3:}

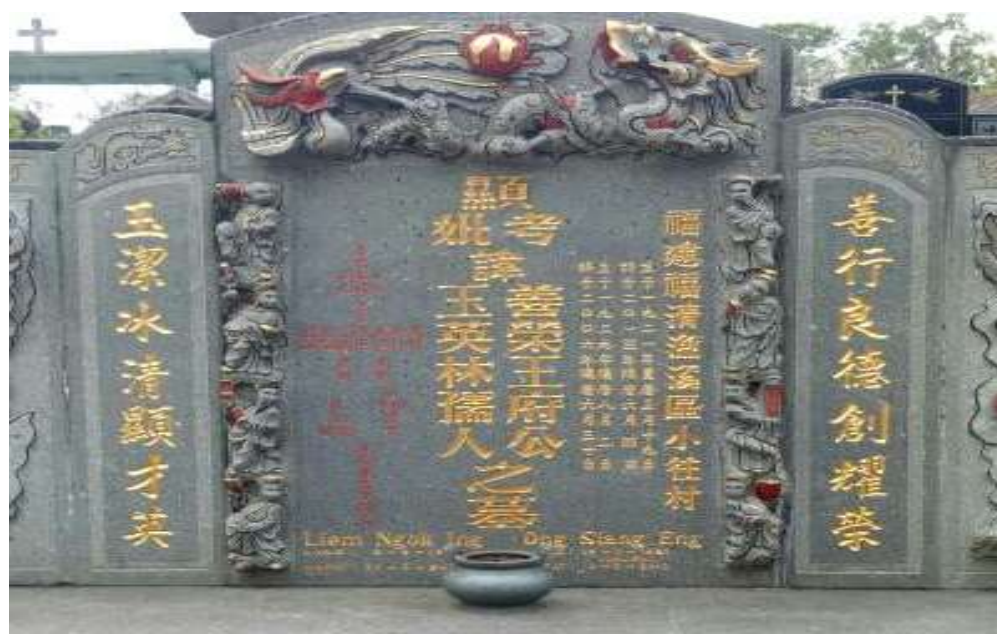

Tulisan aksara Han yang terdapat pada baris kanan Bongpay adalah nama daerah keluarga mendiang berasal, tanggal lahir dan tanggal wafat mendiang ayah dan mendiang ibu menggunakan penanggalan masehi. Nama daerah asal keluarga mendiang yaitu di desa 小往 (Xiăowăng), daerah 福清 (Fúqīng), provinsi 福建 (Fújiàn). Di sebelah kiri nama daerah bertuliskan tanggal lahir mendiang ayah yaitu 19 Mei 1921 (一九二一年五月十九日 yījiǔ èr ȳ̄ nián wŭ yuè shí jiŭ rì), dan tanggal wafat mendiang ayah yaitu 4 Juni 2013 (二0一三年六 月四日 èr líng ȳ̄ sān nián liù yuè sì rì). Tanggal lahir mendiang ibu yaitu 2 Agustus 1926 (一 九二六年八月二日 ȳ̄ jiŭ èr liù nián bā yuè èr rì), dan tanggal wafat mendiang ibu yaitu 30 Juni 2006 (二0 0 六年六月三十日 èr líng líng liù nián liù yuè sān shí rì).

Pada baris tengah bertuliskan nama mendiang ayah, nama mendiang ibu. Nama mendiang ibu ditulis di sebelah kiri nama mendiang ayah. Di atas nama mendiang ayah terdapat kata 显考讳(xiăn kăo huì) yang artinya nama mendiang ayah. Nama mendiang ayah adalah 善荣 (Shànróng), dan marga mendiang ayah adalah 王 (Wáng). Di atas nama mendiang ibu terdapat kata 显妣讳(xiăn b̆ huì) yang artinya nama mendiang ibu. Nama mendiang ibu adalah 玉英 (Yùyīng), dan marga mendiang ibu adalah 林 (Lín). Di bagian bawah nama mendiang terdapat kata 之墓 (zhì mù) yang artinya pemilik makam. Di bagian bawah ini, bertuliskan nama mendiang ayah dan nama mendiang ibu, tanggal lahir dan tanggal wafat yang ditulis dalam bahasa Indonesia. 
Selanjutnya, pada baris kiri bertuliskan nama-nama putra, nama-nama putri, nama cucu laki-laki, dan nama cucu perempuan mendiang. Nama-nama putra, putri dan cucu mendiang yang berwarna merah, menandakan bahwa putra, putri dan cucu mendiang tersebut masih hidup.

Pada sisi kanan dan sisi kiri Bongpay bertuliskan petuah dalam bahasa Tionghoa. Petuah tersebut yaitu 善行良德创耀容 (shàn xíng liáng dé chuàng yào róng) diterjemahkan menjadi berkelakuan dan budi pekerti yang baik membuat kebanggaan dan kejayaan; 玉洁冰 清显才英 (yù jié bīng qīng xiăn cái yīng) diterjemahkan menjadi pikiran yang bersih, hati yang suci mencerminkan keunggulan.

\section{KESIMPULAN DAN IMPLIKASI}

Dari analisis yang telah dipaparkan, dapat diambil kesimpulan sebagai berikut:

a. Penerjemahan aksara Han pada Bongpay di Muntang-Tanjung Banyumas menggunakan metode komunikatif dapat lebih mudah dalam memahami maknanya, tanpa merubah isi pesan yang terdapat dalam bahasa sumber.

b. Tulisan aksaran Han pada Bongpay terdiri dari empat bagian, namun dalam penulisannya tidak semua sesuai berdasarkan bagian-bagiannya.

1) Pada baris kanan bertuliskan tanggal lahir, dan tanggal wafat mendiang. Namun terdapat juga penulisan tanggal mendiang dimakamkan, dan penulisan nama asal daerah keluarga mendiang pada baris kanan ini. Umumnya penulisan nama asal daerah keluarga mendiang terdapat pada baris horizontal atau mata Bongpay.

2) Pada baris tengah bertuliskan nama mendiang ayah, dan nama mendiang ibu. Nama mendiang ibu ditulis di sebelah kiri nama mendiang ayah. Jika ayah memiliki istri lebih dari satu. Maka, nama mendiang istri pertama ditulis di sebelah kanan nama mendiang ayah, kemudian nama mendiang istri kedua dan ketiga ditulis di sebelah kiri nama mendiang ayah. Penulisan nama asal daerah keluarga mendiang juga terdapat pada baris tengah ini, yaitu pada sisi kanan nama mendiang ayah dan pada sisi kiri nama mendiang ibu.

3) Pada baris horizontal atau mata Bongpay bertuliskan nama daerah keluarga mendiang berasal, ditulis dalam bentuk vertikal.

4) Pada baris kiri bertuliskan nama-nama putra, nama-nama putri, nama cucu laki-laki dan nama cucu perempuan. Jika nama putra, putri dan cucu-cucu mendiang berwarna merah menandakan bahwa putra, putri dan cucu-cucu mendiang tersebut masih hidup, namun jika nama putra dan nama putri mendiang berwarna kuning atau emas menandakan bahwa putra dan putri mendiang tersebut sudah meninggal. Penulisan tanggal peletakan batu nisan juga 
ditulis pada baris kiri ini dengan menggunakan penanggalan masehi dan penanggalan Tiongkok.

5) Ada beberapa makam tradisional Tiongkok yang menuliskan kata petuah pada sisi kanan dan sisi kiri Bongpay menggunakan bahasa Tionghoa.

\section{DAFTAR PUSTAKA}

Aksara Han Tradisional. https://id.m.wikipedia.org/wiki/Aksara-Han-tradisional Husodo, Siswono Judo. 1985. Warga Baru (Kasus Cina di Indonesia). Lembaga Penerbitan Yayasan padamu Negeri. Jakarta.

Milawati. "Sejarah Cina di Indonesia". http://wawasansejarah.com/sejarah-cina-di-Indonesia/ (diakses 22 Mei 2016)

Nio Joe Lan. 1961. Peradaban Tionghoa: Selayang Pandang. Keng Po. Jakarta

Newmark, Peter. 1981. Approaches to Translation. Permagon Press. Oxford

Newmark, Peter. 1988. A Textbook of Translation. Prentice Hall International Ltd. Hertfordshire

Ode, M.D La. 2012. Etnis Cina Indonesia dalam Politik: Politik Etnis Cina Pontianak dan Singkawang di Era Reformasi 1998-2008. Yayasan Pustaka Obor Indonesia. Jakarta. Sayogie, Frans. 2014. Teori dan Praktik Penerjemahan. Transpustaka. Tangerang.

Tan, Herman. "Cara Membaca Penulisan Bongpay di Makam Tionghoa”. https:// www.tionghoa.info/cara-membaca-penulisan-bongpay-di-makam-tionghoa/. (diakses 29 Maret 2014)

\section{Data Penulis}

$\begin{array}{ll}\text { Nama } & : \text { Nurhayati } \\ \text { Prodi } & : \text { D3 Bahasa Mandarin } \\ \text { Perguran Tinggi } & : \text { Universitas Jendral Soedirman, Purwokerto } \\ \text { Nomor HP } & : \text { 0819 } 32352189 \\ \text { Alamat Email } & : \text { nuoni.zf@gmail.com }\end{array}$

